\title{
Research Article: Development of nutrient enriched animal feed from tomato pomace waste under solid state fermentation
}

Article Chronicle: Received : 19.07.2017; Accepted : 03.08.2017

\section{KeY WoRDS :}

Tomato pomace, Supplementation, Yeast, Lactic acid bacteria, Nutrient enrichment, Animal feed

\section{H.N. ROJA, R. VEENA, M.B. DARSHAN, K.B. MUNISHAMANNA AND V. PALANIMUTHU}

SUMMARY : Tomato pomace is a mixture of peels, seeds and small amount of pulp with high moisture content that remains after industrial processing. The limitation in utilization of fresh tomato pomace as animal feed is because of its high moisture and fibre contents. Presently, huge quantity of this valuable by product waste is either composted or dumped in landfills, roadsides or rivers leading to environmental hazards. Hence, anexperiment on solid state fermentation industrial processed tomato pomace supplemented with different organic sources (azolla, soybean cake, groundnut cake, maize grits) and fermented by probiotic yeast (Saccharomyces boulardii) and lactic acid bacteria (Lactobacillusplantarum, MTCC 6161)was studied for the development of nutrient enriched animal feed. The results revealed that tomato pomace supplemented with soybean cake (15\%) and combined fermentation by yeast and lactic acid bacteria showed highest protein $(23.85 \%)$, fat (10.36\%), mineral Calcium $(1750.0 \mathrm{mg} / 100 \mathrm{~g})$ and more reduction in fibre (16.69\%) compared to other treatments. However, the results clearly indicated that the tomato pomace supplementing with different nitrogen sources and combined fermentation by yeast and bacteria a showed significant enhancement in nutrients with respect to protein, fat, minerals and reduction in the fibre in the fermented tomato pomace which are essential as animal feed supplements. The results conclude that supplementation and fermentation helps to enrich the nutrients in tomato pomace waste which could be a very good source of animal feed supplement.

How to cite this article : Roja, H.N., Veena, R., Darshan, M.B., Munishamanna, K.B. and Palanimuthu, V. (2017). Development of nutrient enriched animal feed from tomato pomace waste under solid state fermentation. Agric. Update, 12(TECHSEAR-7) : 2020-2030; DOI: 10.15740/HAS/AU/12.TECHSEAR(7)2017/2020-2030.

Author for correspondence :

\section{R. VEENA}

AICRP on Post Harvest Engineering and

Technology, University of Agricultural Sciences, GKVK, BENGALURU (KARNATAKA) INDIA Email : veenadsc@ yahoo.com

See end of the article for authors' affiliations 